\title{
Correction to: Modelling and Simulation of Power Electronic Converter Dominated Power Systems in PowerFactory
}

Francisco M. Gonzalez-Longatt and José Luis Rueda Torres

Correction to:

F. M. Gonzalez-Longatt and J. L. Rueda Torres (eds.), Modelling and Simulation of Power Electronic Converter Dominated Power Systems in PowerFactory, Power Systems, https://doi.org/10.1007/978-3-030-54124-8

The original version of the book was inadvertently published with incorrect affiliation of Dr. Abdul W. Korai. The correct affiliation has been updated in the chapters 8, 9, 11,13 , and 14. The Correction chapters and book has been updated with the changes.

The updated version of these chapters can be found at https://doi.org/10.1007/978-3-030-54124-8_8 https://doi.org/10.1007/978-3-030-54124-8_9 https://doi.org/10.1007/978-3-030-54124-8_11 https://doi.org/10.1007/978-3-030-54124-8_13 https://doi.org/10.1007/978-3-030-54124-8_14

F. M. Gonzalez-Longatt $(\varangle)$

University of South-Eastern Norway, Porsgrunn, Norway

J. L. Rueda Torres

Department of Electrical Sustainable, Delft University of Technology, Delft, Zuid-Holland, The Netherlands 